\title{
2 \\ Cold War Discursive Hegemony: Anticommunism, Americanism and Antagonism
}

Communism can be worse than the Nazis or fascists. In practice, it is more terrible than dictatorship.

$$
\text { - King Bhumibol Adulyadej (1967) }{ }^{1}
$$

We in Thailand want to coexist with everyone including Communist countries, but the trouble is that some Communist countries do not want to coexist with us. They want to wipe us out of our existence, or they want to control us as you may have seen. Beijing has started to say that they declared guerrilla war on Thailand. Well, this is not coexistence. This is the opposition to coexistence ... God should condemn us to make accommodation with the Communists.

- Thanat Khoman, foreign minister $(1967)^{2}$

\footnotetext{
1 King Bhumibol, interview, Look magazine, 1967, quoted in Jim Algie, et al., Americans in Thailand (Singapore: Editions Didier Millet, 2014), 189.

2 Thanat Khoman, 'Interview given by Foreign Minister Thanat Khoman to Japanese Pressmen', at the Ministry of Foreign Affairs, Bangkok, 10 July 1967, in Collected Interviews of H.E. Dr. Thanat Khoman, Minister of Foreign Affairs of the Kingdom of Thailand, Vol. 1: 1967 (Bangkok: Department of Information, Ministry of Foreign Affairs, 2014), 52-53; Thanat Khoman, 'Interview given by Foreign Minister Thanat Khoman to Mr. Walker Stone, Editor-in-Chief of the Scripps-Howard Newspapers', Bangkok, 27 September 1967, in Collected Interviews of H.E. Dr. Thanat Khoman, Vol. 1: 1967, 111.
} 
It is impossible to understand the emergence of 'bamboo' diplomacy in the long 1970s without first tracing how anticommunism became hegemonic in the late 1950s. This chapter examines how anticommunist discourse emerged out of a discursive struggle within Thai politics and foreign policy formation; it is divided into two main parts. The first part discusses the struggles and clash between four contradictory and competing discourses - or myths - of Thai diplomacy: discourses of independence, lost territory, anticommunism and flexible diplomacy. It elucidates the power struggle between royal nationalism and military nationalism, which set the context for the emergence of anticommunist discourse in the Cold War, as well as the countervailing discourse of flexible diplomacy. The second part specifically examines the descent and emergence of anticommunism, from the late nineteenth century until the military regimes under Field Marshals Sarit Thanarat (1958-1963) and Thanom Kittikachorn (19631968). It argues that although the concept of anticommunism predated the rise of active communism in Thailand; it was merely used as a tactic to hinder antiradical discourses, to destroy political enemies and to justify the status quo. It was only from the coup in 1958 that anticommunism became a hegemonic discourse. This discourse not only demonised the communist threat but also shaped anticommunist identity and practices. Thai foreign relations with the communist powers including the USSR and the People's Republic of China (PRC) were largely framed by this Cold War discursive hegemony.

\subsection{Discursive Struggles in Thailand}

The discourse of anticommunism was one among many foreign policy discourses in Thailand. Since the formation of the modern Thai state in the nineteenth century, Thailand had at least four faces, or myths, upon which diplomacy was based, namely the discourses of independence, lost territory, anticommunism and flexible diplomacy. These four myths shaped the way in which Thailand perceived itself in the world as well as how a 'threat' was constructed in different periods of time. Discursive hegemony happened when one discourse became dominant at a particular time. It defined conventional wisdom and marginalised other understandings. However, this does not mean that one discourse totally replaced another. On the contrary, new discourses tended to emerge alongside, and in contradiction with, older ones. Sometimes old discourses faded away, sometimes they discredited the new one. 
During the Cold War, Thailand encountered the discursive struggle between these consecutive myths. The first discourse is that of independence. This is a royal nationalist narrative of Thai diplomacy that emerged out of the late nineteenth century. It asserts that Thailand is a unique or exceptional country in Southeast Asia in two senses: first, Thailand, unlike others in the region, was never colonised by Western imperialist powers. Second, Thailand cannot be compared with other countries. $^{3}$ This discourse of independence remains a dominant discourse. The narrative goes that Thailand was a 'victim' of Western imperialism/colonialism and it interprets French imperialism during the Franco-Siamese crisis of 1893 as a 'threat' that was defeated by the Thai establishment. In other words, the monarchy is portrayed as an institution that helped save the country from imperialist expansionism and should be considered saviour of the nation. ${ }^{4}$ The discourse of independence has thus empowered royal hegemony. ${ }^{5}$ It also forms the national status and identity of Thailand as an independent state, which means not being colonised.

The second discourse is that of the lost territory or 'national humiliation'. The royalist discourse of independence was not directly challenged until after the 1932 Revolution, which ended the absolute monarchy. The discourse of lost territory emerged during the first administration of Field Marshal Plaek Phibunsongkhram, aka 'Phibun' (1938-1944). This saw a shift from royal nationalism to military nationalism. This discourse was a 'tool for delegitimizing state leadership', particularly the monarchy, and 'an effective way to discredit political opponents' ${ }^{6}$

3 See David Wyatt, Thailand: A Short History (New Haven: Yale University Press, 1984); Pensri Duke, Karntangprated kub aekkarat lae attippatai kong thai [Foreign Affairs and Thailand's Independence and Sovereignty, since King Rama V to the Phibun Government] (Bangkok: The Royal Institute, 1999). Benedict Anderson bluntly observes that 'what damn good is this country - you can't compare it with anything'. See his 'Studies of the Thai State: The State of Thai Studies', in Exploration and Irony in Studies of Siam over Forty Years (Ithaca: Cornell University, 2014), 15-46.

4 See Patrick Tuck, The French Wolf and the Siamese Lamb: The French Threat to Siamese Independence, 1858-1907 (Bangkok: White Lotus Press, 1995). Thongchai Winichakul critically interrogates this metanarrative. See his Siam Mapped: A History of the Geo-Body of a Nation (Honolulu: University of Hawai i Press, 1994).

5 Thongchai Winichakul terms it 'rachachatniyom' [royalist nationalism]. See his Prawatisat thai baep rachachatniyom: Jak yuk ananikhom amphrang su rachachatniyom mai rue latthi phor khong kradumphi thai nai patchuban [Royalist Nationalist History: From the Colonial Era to the New Royalist Nationalism], Silapawatthanatham 23, no. 1 (November 2001): 43-52.

6 Shane Strate, The Lost Territories: Thailand's History of National Humiliation (Honolulu: University of Hawai'i Press, 2015), 3. 
In The Lost Territories, Shane Strate elegantly argues that Phibun's nationalist diplomacy heavily depended on the discourse of 'lost territory while reassigning [the discourse of] never colonized to a subordinate role':

In order to construct an anti-imperialist discourse that would mobilize an entire nation, the government downplayed Siam's legacy of independence and instead interpreted the FrancoSiamese crisis of 1893 as a defeat that robbed the nation of both its territory and its honour. The leaders of Thailand provoked the 1941 war with French Indochina because they felt confident that avenging the loss from a half century earlier would allow the military to replace the monarchy in the role of national saviour. ${ }^{7}$

The crisis of 1893 was redefined as a collective 'trauma' and loss of sovereignty, while the alliance with Japan, and the 1941 war with France in Indochina, was portrayed as redemption. In turn, the military, instead of the monarchy, was presented as the national 'hero'. However, the Japanese (coupled with Thai) defeat at the end of the Second World War delegitimised, yet did not end, this second discourse. The latter persists as a powerful discourse. ${ }^{8}$ Throughout the history of Thai diplomacy, both independence and lost territory discourses have been in a state of discursive tension.

The third discourse is anticommunism. Although this discourse began in the late nineteenth century to discredit any radical discourses and support the status quo, ${ }^{9}$ it emerged as a dominant narrative or knowledge only after the 1958 coup of Field Marshal Sarit Thanarat, when he became the prime minister himself. Following his visit to Washington DC, Sarit installed a new military regime and unquestionably aligned with the US. Within this discourse, the communists - which included the powers of the Soviet Union and the PRC - were demonised as vital threats to national interest and survival. While Thailand had diplomatic relations with the USSR since 1941 and no formal relations with the PRC, Thai foreign relations with both powers were mutually antagonistic. The anticommunist discourse also positioned Thailand as an inviolable part of the Free World, where the US led and promised to guarantee its independence.

$7 \quad$ Strate, The Lost Territories, 4.

8 This discourse was revivified during the losing Preah Vihear incident in 1962, which has persisted in Thai politics until recently.

9 Kasian Tejapira, Commodifying Marxism: The Formation of Modern Thai Radical Culture, 19271958 (Australia: Trans Pacific Press, 2001). 
The last discourse is that of flexible diplomacy. This is the idea that Thai foreign policy is firmly grounded in a basic pragmatism that 'bends with the wind'. The ultimate objective is Thailand's survival and independence, and it is therefore described as 'bamboo' diplomacy. ${ }^{10}$ In conventional historiography, the monarchs were portrayed as gifted leaders who saved the country from external threats. ${ }^{11}$ Thamsook Numnonda also reinterprets Phibun's foreign policy as inherently flexible. As she puts it, 'the Thai art of [bamboo] diplomacy had once again saved the country. And this, of course, has always been the way the Thais have met and overcome every crisis'. ${ }^{12}$ This discourse of flexible diplomacy is powerful in the sense that, first, it conveniently blends the discourses of independence and lost territory, and second, it demonstrates continuity in Thai diplomacy since the nineteenth century. This book argues differently, claiming that this discourse emerged out of the détente strategy and a concomitant historiography in the 1970s. Moreover, it was a discourse of diplomats.

To sum up, each discourse constituted a historical narrative as well as the national identity and interest at different times, which in turn determined who or what was treated as a 'threat' from within and without. Different discourses heralded the transformation of domestic subject positions. By the late 1950s, the anticommunist discourse, coupled with the anticommunists, started to dominate Thai politics and foreign affairs.

\subsection{The Emergence of Anticommunism}

\subsubsection{Anticommunism as a Tactic (Before 1958)}

This section argues that the idea of anticommunism predated the emergence of active communism in Thailand. It emerged in the late nineteenth century as a reaction of Thai royalism to any anti-royalist, radical discourses. Anticommunism was fundamentally employed during both the absolutist and early democratic eras as a political tool to curb or combat local enemies. In Cold War Thailand, while communism was

10 See Likhit Dhiravegin, 'Thailand Foreign Policy Determination', The Journal of Social Sciences 11, no. 4 (1974): 37-65; Arne Kislenko, 'Bending with the Wind: The Continuity and Flexibility of Thai Foreign Policy', International Journal 57, no. 4 (Autumn 2002): 537-61.

11 See Likhit Dhiravegin, Siam and Colonialism (1855-1909): An Analysis of Diplomatic Relation (Bangkok: Thai Wattana Panich, 1975).

12 Thamsook Numnonda, Thailand and the Japanese Presence, 1941-1945 (Singapore: Institute of Southeast Asian Studies, 1977), vi. 
highlighted as a red menace during the second Phibun administration (1948-1957), the idea of anticommunism before 1958 was first and foremost a tactic in bargaining with the US for military aid. That is, anticommunism was an idea without any genuine communists.

The origin of anticommunism in Thailand can be traced back to the late nineteenth century. In 1881, King Chulalongkorn reportedly told American Consul-General John A Halderman that all rulers in the world would someday be saved by Providence from 'those based classes Socialist, Nihilist, Communists etc'. ${ }^{13}$ In 1912, his son, King Vajiravudh, alarmed by domestic (the attempted coup in March 1912) and international (Chinese Republican Revolution in October 1911 and subsequent abdication of the Manchu emperor in February 1912) factors, wrote diary entries on a critique of what he called 'the doctrine of socialism' (latthi khong sochialist). The latter was preached as impractical and unrealistic. ${ }^{14}$ From then, the terms 'communism' and 'socialism' were used interchangeably. Both were counted as equivalent forms of radical discourses. ${ }^{15}$

Nevertheless, only a few Thai students were influenced by Western radical or progressive discourses (such as Pridi Phanomyong and Prince Sakol Wannakon Worawan, alias the 'Red Prince'). Communism, on the other hand, was strictly limited to Chinese and Vietnamese immigrants. For Kasian Tejapira, their main aim was 'externally oriented and anti-imperialist'. The spectre of communism was thus 'less menacing' but 'more alien' to the Thais. ${ }^{16}$ From the outset, it was an un-Thai ideology. However, after the collapse of the Kuomintang-Chinese Communist Party alliance in 1927 and a shift in the Comintern's strategy toward the so-called 'Third Period' of ultra-leftism in 1928, an increase in communist activities in Thailand precipitated the severe crackdown by the Thai Government in 1929. The latter led to a series of deportations

13 Quoted in Benjamin Batson, The End of the Absolute Monarchy in Siam (Oxford: Oxford University Press, 1985), 165.

14 Quoted in Kasian, Commodifying Marxism, 13-14.

15 On the emergence of radical and republican discourses, see Craig J Reynolds and Hong Lysa, 'Marxism in Thai Historical Studies', Journal of Asian Studies 43, no. 1 (1983): 77-104; Craig J Reynolds, Thai Radical Discourse: The Real Face of Thai Feudalism Today (Ithaca: Cornell Southeast Asia Program Publications, 1987); Patrick Jory, 'Republicanism in Thai History', in A Sarong for Clio: Essays on the Intellectual and Cultural History of Thailand, ed. Maurizio Peleggi (Ithaca: Cornell Southeast Asia Program Publications, 1987, 2015): 97-117.

16 Kasian, Commodifying Marxism, 18. 
and imprisonments. At the same time, this event triggered a new turn to communism in Thailand and the Communist Party of Siam was established in $1930 .{ }^{17}$

After the 1932 Revolution - which ended Thai absolutism anticommunism and, particularly, anti-Chinese policies continued under successive People's Party governments. During this period, communism was mainly used as a political tool to delegitimise political opponents in Thai politics. In his royal critique, or so-called Samud pokkhao, King Rama VII himself attacked Pridi, leader of the civilian wing of the People's Party, and his Economic Plan (Samud pokleuang) as 'Communist'. He was quoted as saying:

I do not know whether Stalin copied [Pridi] or whether [Pridi] copied Stalin ... the only difference is that one is Russian, the other Thai ... This is the same program that has been used in Russia. If our government adopted it, we would be assisting the Third International to achieve the aim of world Communism ... Siam would become the second Communist state after Russia. ${ }^{18}$

Eventually, Pridi went into exile, whereas the first Anti-Communist Act was enacted on 2 April 1933. The definition of 'Communism' in the Act was vague and extremely broad. According to Kasian, it was 'veritably not anticommunist at all, but anti-socialist, or more specifically, anti-Pridi, anti-left wing of the People's Party, and anti-Economic Plan'. ${ }^{19}$

The definition of communism was revised after the second military coup in 1933. The 1935 Amendment to the Anti-Communist Act was instead to exclude socialist reformists, including Pridi and his left-wing fellows. It continued to target the communists. Communist activities in Thailand drastically faded away when the Communist Party of Siam declined in 1936. Then, from 1938, the Phibun Government pursued nationalist policies.

17 See Christopher E Goscha, Thailand and the Southeast Asian Networks of the Vietnamese Revolution, 1885-1954 (London and New York: Routledge, 1999); Eiji Murashima, The Early Years of Communism in Thailand (1930-1936) (Bangkok: Matichon, 2012).

18 Quoted in Judith Stowe, Siam Becomes Thailand: A Study of Intrigue (Honolulu: University of Hawai'i Press, 1991), 37-38.

19 Kasian, Commodifying Marxism, 39. 
During the Second World War in the Pacific, the rise of anti-Japanese, anti-Phibun movements provided new opportunities for communist activities in Thailand. However, the number of Thai communists in the post-Second World War era remained very small and their influence marginal..$^{20}$ In addition, with the active domestic support of Pridi, the Anti-Communist Act was repealed in September 1946 in order to gain Soviet endorsement for Thailand's membership in the United Nations.

When Phibun returned to power in early 1948, anticommunism was not his primary agenda. Phibun was indifferent to ideology, which was explicit in his policy toward local Chinese and communists. 'Anticommunist' repression happened only when the US subsequently pushed the agenda on the Thai elite. ${ }^{21}$ As Fineman puts it, ideology 'maintained only a minor role in the Thai political system' in the $1950 \mathrm{~s}^{22}$

What changed Phibun's foreign policy orientation was the quest for military aid from the US, which he considered as imperative for the fate of the military regime. At first, the US opposed the Phibun Government and rendered military aid politically undesirable. ${ }^{23}$ But by early 1949 , US policymakers came to concur that foreign aid would be a tool to strengthen Thailand's will to resist communism. ${ }^{24}$ It heralded Thailand's increasing importance to America's anticommunist policy in the region.

Phibun's shift toward a pro-American stance was shown in his (at least rhetorically) self-portrayal as a hardline anticommunist. Following the victory of Chinese communism in October 1949, he supported the Bao Dai and Korean War decisions in 1950. Despite the initiation of Military Assistance Agreement in October 1950, US military assistance

20 Kasian, Commodifying Marxism, 26.

21 Daniel Fineman, A Special Relationship: The United States and Military Government in Thailand, 1947-1958 (Honolulu: University of Hawai i Press, 1997); Soymook Yingchaiyakamon, 'Thailand's Foreign Policy towards the People's Republic of China during Field Marshal P. Phibulsonggram's Government (1948-1957)', (MA thesis, Chulalongkorn University, 2001).

22 Fineman, A Special Relationship, 75. Historiographically, Fineman transcends the predominant Cold War paradigm, or what he called 'international-relations-oriented studies' (5), which explains the alliance from an ideological perspective, namely anticommunism. This paradigm 'fails to explain the role of the military and military-controlled governments in the alliance' (4). Fineman asserts instead that 'rather than considering Thailand's alliance with the United States as separate from internal politics and driven by the novel and imported ideology of anticommunism, as the Cold War model assumes, we should view the country's domestic politics and foreign policy, as the Thais themselves did, as closely connected' (4).

23 See Edwin F Stanton, Brief Authority: Excursions of a Common Man in an Uncommon World (New York: Harper, 1956), 209.

24 Frank C Darling, Thailand and the United States (Washington DC: Public Affairs Press, 1965), 70. 
to Phibun's regime remained 'limited and uncertain', 'significant but modest'. In other words, Thailand still occupied a 'distant place' in US foreign policy thinking. ${ }^{25}$

By the mid-1950s, when the Americans had increased their involvement in Indochina following the French defeat at Dien Bien Phu, Thailand gradually became an American 'bastion' against communism in Southeast Asia. Military aid for Thailand rose dramatically, and the commitment to fight for Thailand's survival was strengthened via the establishment of the Southeast Asia Treaty Organization (SEATO) in September 1954. As the military regime consolidated power over the next five years (1950-1954), Thailand and the US became increasingly close allies. ${ }^{26}$

Following incessant pressures from the US, the Thai military-dominated regime pursued a harsher policy toward communists and dissidents, as well as the Soviet Union and the PRC. In 1952, Phibun banned a Soviet publication named Tass Bulletin, reduced quotas on Chinese immigration and imposed an embargo on all trade with Communist China. ${ }^{27}$ The PRC reacted by announcing the establishment of a Thai Autonomous People's Government in the southern province of Yunnan in 1953. By now, therefore, it was clear that Thailand's pro-American stance was negatively impacting its relations with both the USSR and the PRC. ${ }^{28}$

In domestic politics, the military regime developed a 'triumvirate politics', including such three rivalling strongmen as Phibun, Police General Phao Siyanon and Field Marshal Sarit Thanarat of the Royal Thai Army. ${ }^{29}$ In brief, Thai authoritarianism rose in tandem with American influence in the region. However, during the democratic interlude between 1955 and 1957, proceeding with elections, Phibun allowed political parties to form, lifted restrictions on the press and free speech, revived leftists and dissidents, and intensified the power struggle at the top of the state. This, in turn, saw a deterioration of the Thai-US alliance and the rise of antiAmericanism became ubiquitous in public debate.

25 Fineman, A Special Relationship, 131, 128.

26 Matthew Phillips, Thailand in the Cold War (London and New York: Routledge, 2016), 92-93.

27 Paul R Shirk, 'Thai-Soviet Relations', Asian Survey 9, no. 9 (1969): 690.

28 Anuson Chinvanno, Thailand's Policies towards China, 1949-54 (Hampshire: Macmillan, 1992).

29 Thak Chaloemtiarana, Thailand: The Politics of Despotic Paternalism (Ithaca: Southeast Asia Program Publications, Cornell University Press, 2007). 
Moreover, in foreign affairs, Phibun started to veer toward neutrality and engagement with Beijing. This manifested in the emerging concept of non-alignment, which had developed globally following the Afro-Asian Conference at Bandung in 1955. Phibun sent his foreign minister, Prince Wan Waithayakon, to attend the Bandung Conference, where the latter made an acquaintance with the Chinese Premier, Zhou Enlai. ${ }^{30}$ Phibun also initiated secret diplomacy with the PRC, by sending his unofficial emissary to Beijing. Then he sent two children of Sang Phathanothai, his close confidante, to Beijing as part of a tributary diplomacy. Warnwai, aged 12, and Sirin, aged 8, were raised under the tutelage of Premier Zhou. ${ }^{31}$

It can be stressed that at that time, flexible or bamboo diplomacy was not the formal policy of the country. Phibun's brief moment to engage with China was part of the spirit of Bandung. Neither non-alignment nor neutralisation were epistemically conceived as flexible diplomacy. Furthermore, Thailand's 'China card' was primarily designed by Phibun to pressure the Americans for more aid. ${ }^{32}$ According to Anand Panyarachun, '[Thai foreign policy] during the Phibun administration toward China was not serious. It was merely an insurance policy with fear'. ${ }^{33}$

The Thai non-alignment orientation was short-lived and ended in the military coup in 1957, led by Phibun's own protégé, Field Marshal Sarit Thanarat. The first coup in 1957 was deemed essential because, as a cable to Washington reported, the Phibun Government had 'allowed secret contacts with Communist circles in China'. As US Ambassador to Bangkok, Edwin Stanton, put it, the Thai foreign policy of anticommunism was 'to run with the hare, and hunt with the hounds'. ${ }^{34}$

\footnotetext{
30 Anuson Chinvanno, 'Brief Encounter': Sino-Thai Rapprochement after Bandung, 1955-1957 (Bangkok: Institute of Foreign Affairs, 1991).

31 See Aree Pirom, Buanglang kan sathapana samphanthaparp yukmai thai-jeen [Background to the Establishment of Sino-Thai Relations in the Modern Period] (Bangkok: Mitnara Press, 1981); Warnwai Phathanothai, Zhou Enlai: Pupluek maitri Thai-jeen [Zhou Enlai, The Man Who Planted Thai-Chinese Friendship], 2nd edn (Bangkok: Prakonchai, 1976 [2001]); Sirin Phathanothai, The Dragon's Pearl (New York and London: Simon \& Schuster, 1994).

32 Fineman, A Special Relationship.

33 Anand Panyarachun, 'Patakata pised' [Special Lecture], in Kwam sampan thai-jin [Sino-Thai Relations: Past and Future Prospects], ed. Khien Theeravit and Cheah Yan-Chong (Bangkok: Chualolongkorn University, 2000), 12-13.

34 Quoted in Fineman, A Special Relationship, 244, 66.
} 
In other words, Phibun was not staunchly anticommunist. For him, anticommunism was a means to obtain American military aid and sustain his political survival. Phibun's era in the 1950 s was then a prolegomenon to the genuine 'revolution' under the Sarit Government. ${ }^{35}$ Especially after his second coup in 1958, Sarit abruptly ended his 'democratic' experiment in Thailand, and became strongly committed to anticommunist discourse.

In sum, the term 'anticommunism' was introduced much earlier to Thai political discourse when the Thai monarchy attempted to discredit radical discourses. It served as a political tool to battle domestic political opponents and to justify the political status quo. The demonisation of communism was done even before the existence of Thai communists. Anticommunism was by and large repressive in the sense that Thai governments fought those alleged communists. However, without any genuine communists, they did not and could not produce the new subjects of politically committed anticommunists in the country.

\subsubsection{Anticommunism as a Hegemonic Knowledge (1958-1968)}

This section examines the descent and emergence of anticommunist discourse during the Sarit and Thanom administrations. After 1958, anticommunism began to be the dominant knowledge in Thailand. In turn, the new subject positions of anticommunists, such as the military elites and civilian conservatives, were discursively constructed. By then, anticommunists emerged only when individuals made a strong commitment to this hegemonic discourse of anticommunism and defended it to a hilt. Thailand's close alignment with the US and its involvement in the Vietnam War further deepened this discourse.

35 On the contrary, Fineman claims that the year 1950 was a 'revolution' in Thai diplomacy towards pro-American alignment and anticommunism. I argue differently, that it was merely a 'prelude to revolution', rather than a revolution in itself. This period brought about a transition toward what can be called a 'Cold War discursive hegemony' in the 1960s (specifically, the period after the Sarit coup in 1958 through to 1968). See Daniel Fineman, 'Phibun, the Cold War, and Thailand Foreign Policy Revolution of 1950', in Connecting Histories: Decolonization and the Cold War in Southeast Asia, 1945-1962, ed. Christopher E Goscha and Christopher F Ostenmann (Washington DC and Stanford: Woodrow Wilson Center Press with Stanford University Press, 2009), 275-300. 
After his return from medical treatment at Walter Reed Military Hospital in Washington DC, Field Marshal Sarit Thanarat (1958-1963) launched a second coup in 1958 . He then assumed absolute power domestically. ${ }^{36}$ The coup was endorsed by the king, who was considered by the US State Department as pro-Western and strongly anticommunist. Sarit cited the communist threat as one of the justifications for the coup. He often called the communists 'trouble-makers', and 'our worst enemy, which poses an internal as well as external danger'. ${ }^{37}$

Discursively, communism was demonised as a menace in Thai politics. ${ }^{38}$ Sarit himself rendered it a 'dirty plague'. ${ }^{39}$ Foreign Minister Thanat Khoman (1959-1971) pathologised communism as 'spring fevers, call it red or pink', or 'Asian flu'. By so doing, he used the analogy of a 'doctor' that tried to cure this 'rather vicious virus':

I am glad that one of our doctors has said that the Thais are perhaps the most immune people from the Asian flu, and I wish that I can apply our immunity to that kind of Asian flu. ${ }^{40}$

\section{As Thanat put it:}

We are not going to allow the Asian flu to affect us, in the sense that the students in Paris, or Rome, not to speak of Berkeley or Michigan, who are less immune than we are, and who have been affected by what they euphemistically call the Cultural Revolution.

36 The role of the US in the 1958 coup is debatable. Fineman claims that the US had no role in the coup; however, from Surachart Bamrungsuk we now know that during his medical visit to the US, Sarit had a chance to meet with President Eisenhower and Secretary of State Dulles to discuss a 'free world defense against Communist pressure' as well as the means of strengthening closer ties between Thailand and the US. In contrast, Kullada argues that the US was behind the 1958 coup. Sarit was 'lectured' by the high-ranking US officials, especially US Under-Secretary of State for Economic Affairs, Douglas Dillon, to adopt the 'development' agendas and programs. Surachart Bamrungsuk, United States Foreign Policy and Thailand Military Rule, 1947-1977 (Bangkok: Duang Kamol, 1988), 77; see also Fineman, A Special Relationship; Kullada Kesboonchoo Mead, Kanmueng Thai yuk SaritThanom phaitai khrongsang amnat lok [Thai Politics during Sarit-Thanom Regimes under Global Power Structure] (Bangkok: 50 Years Foundation, The Bank of Thailand, 2007).

37 Thak, Thailand, 127, 136.

38 The anticommunist discourse was mutually shared among Thai elite and public. MR Kukrit Pramoj, a well-renowned royalist and publisher of Siam Rath newspaper, was an ardent advocate of this discourse. See Saichon Sattayanurak, Kukrit kap praditthakam 'Khwam pen Thai', lem 2 [Kukrit and the Construction of 'Thainess', Book 2] (Bangkok: Silapawatthanatham, 2007).

39 Quoted in Puangthong Pawakapan, Truth in the Vietnam War: The First Casualty of War and the Thai State (Bangkok: Kobfai, 2006), 42.

40 Thanat Khoman, 'Statement by Foreign Minister Thanat Khoman to Members of the Foreign Correspondents' Club of Thailand', Bangkok, 28 August 1968, in Collected Interviews of H.E. Dr. Thanat Khoman, Minister of Foreign Affairs of the Kingdom of Thailand, Vol. 2: 1968 (Bangkok: Department of Information, Ministry of Foreign Affairs, 2014), 254-55. 
How can you conceive that the Cultural Revolution can spread from the Empire of the Middle Kingdom [China] to the confines of Europe and America? And how the influence of the Cultural Revolution has surpassed us and bypassed us to go directly to Paris, or to California or to New York, it is beyond my conception. But that is the kind of things that we have to face and perhaps because we keep our eyes firmly on the horizon, scrutinizing openings for future settlement, and keeping our feet firmly on the ground we can escape the nefarious effects of those viruses. We can keep our minds, our hearts and our bodies healthy. ${ }^{41}$

For him, 'we are sick of Communist imperialism'. ${ }^{42}$ And 'if anyone were to think that the Communists have abandoned the scheme of world domination, he is not of the sane mind'. ${ }^{43}$ The spectre of communism was then metaphorically framed as a medical problem that required a series of therapeutic interventions. That was the pathologisation of the other the foreign body perceived to threaten the body politic. To deal with this 'Communist' flu or virus, said Thanat, 'there is no alternative! We prefer to spend money and keep the Communist out rather than have the Communists in'. Thailand fought the 'war against Communist expansion in Southeast Asia' in order to 'eradicate the Communist terrorists' ${ }^{44}$

Sarit believed that Thailand needed a stable military regime in order to simultaneously suppress communism and attract foreign investment. Upon his consolidation of power, he dissolved the National Assembly, closed down many newspapers that were accused of supporting communist activities and banned political organisations and labour unions. The Sarit Government also arrested communist suspects and those who were labelled as communist sympathisers, many of whom included political opponents, journalists, writers and political activists. ${ }^{45}$ In particular, Sarit considered Chinese immigrants a major source of communist

41 Thanat Khoman, 'Statement by Foreign Minister Thanat Khoman to Members of the Foreign Correspondents' Club of Thailand', Bangkok, 28 August, 1968, in Collected Interviews of H.E. Dr. Thanat Khoman, Vol. 2: 1968, 254-55.

42 Thanat Khoman, 'Interview given by Foreign Minister Thanat Khoman to Takashi Oka, The Christian Science Monitor', at the Ministry of Foreign Affairs, Bangkok, 20 January 1967 in Collected Interviews of H.E. Dr. Thanat Khoman, Vol. 1: 1967, 19.

43 Thanat Khoman, 'Interview given by Foreign Minister Thanat Khoman to Mr. Rafael Steinberg from the Saturday Evening Post', at the Ministry of Foreign Affairs, Bangkok, 25 September 1967, in Collected Interviews of H.E. Dr. Thanat Khoman, Vol. 1: 1967, 104-5.

44 Thanat Khoman, 'Interview given by Foreign Minister Thanat Khoman to a Group of Scandinavia's Newspapermen', Bangkok, 9 November, 1967, in Collected Interviews of H.E. Dr. Thanat Khoman, Vol. 1: 1967, 126.

45 Thak, Thailand. 
infiltration. In May 1959, for instance, his government restricted Chinese immigration in order to curb the domestic communist insurgency. It also arrested a group of Thai actors who went to Beijing. They were charged with being involved in communist activities. Four of them were accused of being communist leaders, and executed by the special powers under Article 17 of the Interim Constitution of Thailand (1959). ${ }^{46}$ Henceforth, the military regime took a strong anticommunist policy.

Deeply embedded in anticommunist discourse, Sarit's foreign policy was a major shift from Phibun's. He abruptly ended the latter's attempted strategy of neutrality and accommodation with the PRC. For Sarit, neutrality or non-alignment was vulnerability to the communist threat. Foreign Minister Thanat said, in retrospect, that the idea of non-alignment became a 'bankrupt concept' because the communists were 'not willing to uphold the original concept of peaceful coexistence', which was 'a necessary premise or a necessary foundation for the policy of non-alignment'. ${ }^{47}$ By 1958 , the spirit of Bandung faded away in Thailand temporarily and Thai state actors advocated a close alliance with the US. Thanat justified the necessity of a 'protective umbrella' by claiming that there

are only two umbrellas in the world, either the Soviet or American umbrella. We cannot hope to have the Soviet umbrella. So, we shall have to use the only one available, the American umbrella. ${ }^{48}$

Sarit's foreign policy was based on the following characteristics. First, it strengthened Thai-US relations. The year 1958 marked a historical watershed because it restored and consolidated the Thai-US special relationship. As Fineman has put it, in 1958:

the question was whether the Americans would stand firmly behind the democratic process or selectively intervene on behalf of the elected government's opponents. They chose the latter, and democracy paid the price. ${ }^{49}$

46 Surachart, United States Foreign Policy and Thailand Military Rule, 106-7.

47 Thanat Khoman, 'Interview given by Foreign Minister Thanat Khoman to a Group of New Zealand Reporters', at the Ministry of Foreign Affairs, Bangkok, 7 September 1967, in Collected Interviews of H.E. Dr. Thanat Khoman, Vol. 1: 1967, 69.

48 Thanat Khoman, 'Interview given by Foreign Minister Thanat Khoman to Mr. Tom Wicker, Washington Bureau's Chief of the New York Times', Bangkok, 8 February 1967, in Collected Interviews of H.E. Dr. Thanat Khoman, Vol. 1: 1967, 33.

49 Fineman, A Special Relationship, 13. 
'The Americans had not embraced military dictatorship in Thailand in 1958 because they had no other choice', rather, the Americans enthusiastically embraced military authoritarianism because it aligned with their strategic interests. ${ }^{50}$ This was the foundation of the so-called 'special relationship' between Thailand and the US throughout the Cold War. Both countries were intimately interdependent. While, on the one hand, Thai military stability and survival largely relied on American military and economic aid, the US, on the other hand, depended on Thailand's congenially strong, stable and pro-American military regime. This was not a coincidence, but a mutual construction. However, this alliance was a 'tragedy' for Thai democratisation. ${ }^{51}$

For Thailand, an alliance with the US was rooted in a number of assumptions: their shared belief in the domino theory; the US commitment to defend Thailand from communism; and US military assistance and aid in supporting counterinsurgency warfare. The US started to develop air bases and military facilities, thereby using Thailand as forward defence stations in the region. ${ }^{52}$ Sarit's pro-American strategy was a pretext for an ever-closer alliance during the Vietnam War in the 1960s.

Second, the Sarit regime reaffirmed Thailand's commitment to SEATO. However, the alliance was significantly tested during the deteriorating situation in Laos in 1960-1962. The crisis began when the right-wing government, led by Phoumi Nosavan, who was also Sarit's cousin, was overthrown by communist forces, or the Pathet Lao, in August 1960. The Sarit Government expressed its dissatisfaction with SEATO and the US Government, which were reluctant to use military force to support the anticommunist factions. Sarit reportedly began to negotiate with the Soviet ambassador on trade and cultural exchanges as a bargaining tool vis-à-vis the US. ${ }^{53}$ Sarit even threatened to withdraw from SEATO before President John F Kennedy agreed to promulgate the Thanat-Rusk joint communiqué in March 1962. The communiqué was aimed to reaffirm

50 Fineman, A Special Relationship, 262.

51 Fineman, $A$ Special Relationship, 8. See also Kullada Kesboonchoo Mead, 'The Cold War and Thai Democratization', in Southeast Asia and the Cold War, ed. Albert Lau (London and New York: Routledge, 2012), 215-40.

52 See Surachart, United States Foreign Policy and Thailand Military Rule.

53 Jittipat Poonkham, Withet Panid Sampan tung Songkram Yen: kwam sampan rawangprathet Thai-Russia (1897-1991) [Foreign Economic Relations to the Cold War: Thai-Russian Foreign Relations (1897-1991)] (Bangkok: Chulalongkorn University Press, 2016), 92-94. 
the US military commitment to Thailand. It stated that the US would protect Thailand from 'Communist aggression and subversion' by giving full support under 'its constitutional process'. ${ }^{54}$

While the Thanat-Rusk communiqué was in fact a 'bilateralization of SEATO' without any clear substance, ${ }^{55}$ the military regime viewed it as a significant assurance. After that, the US supplied Phoumi's right-wing troops and trained the indigenous Hmong tribes under Vang Pao. In May 1962, the US ordered a carrier task force of the 7th Fleet into the Gulf of Thailand, and deployed 5,000 US troops, US jet bombers and 1,800 US marines in Thailand. ${ }^{56}$

The crisis in Laos obviously indicated a divergence of perceptions and strategies between Thailand and the US. ${ }^{57}$ First, the Laotian crisis was perceived as an immediate threat to Thailand. If the Phoumi's faction in Laos collapsed, Thailand would become a 'frontline state'. In turn, Laos would provide a support base for the Communist Party of Thailand (CPT). Furthermore, the Thai military advocated a forward defence strategy, by fighting outside the country. As Field Marshal Thanom Kittikachorn later explained: 'It is better for Thailand to fight the enemy away from home than wait for him to arrive at one's door. 58

The third characteristic of Sarit's foreign policy was its antagonism towards the Soviet Union and the PRC. On the one hand, the Sarit Government continued to be sceptical of Soviet activities in Bangkok. In 1959, it declared the Soviet attaché 'persona non grata' and expelled the Russian news agency Tass journalist. However, Sarit also used the 'Soviet' card as leverage with the Americans when Thai-US relations turned sour. During the Laotian crisis, he talked about the possibility of trade relations with the Russians, and even exchanged formal Trade Notes. ${ }^{59}$ Yet, it did not come to any concrete outcomes.

54 Quoted in R Sean Randolph, The United States and Thailand: Alliance Dynamics, 1950-1985

(Berkeley: Institute of East Asian Studies, University of California, 1986), 41.

55 Surachart, United States Foreign Policy and Thailand Military Rule, 103.

56 Surachart, United States Foreign Policy and Thailand Military Rule, 105.

57 On the Laotian crisis, see Sutayut Osornprasop, 'Thailand and the American Secret War in Indochina, 1960-1974' (PhD thesis, University of Cambridge, 2006).

58 New York Times, 2 June 1970, quoted in Sutayut, 'Thailand and the American Secret War', 230.

59 Jittipat, Withet Panid Sampan tung Songkram Yen, 92-94. 
On the other hand, Sarit terminated Phibun's initial accommodation with China. He issued Revolutionary Proclamation No. 53 in 1959, which banned trade with China. Sarit also strengthened the Anti-Communist Act, thereby pursuing a repressive crackdown upon domestic communist insurgents, or even communist sympathisers. ${ }^{60}$

His anticommunist and anti-Beijing policies were affirmed by a reversal of the PRC's stance in 1957-1958, and the increasingly proactive role of the CPT. By the end of 1957, Beijing resumed a militant, aggressive international policy. It increased the level of Chinese anti-Thai propaganda. In 1962, with Chinese support, the Voice of the People of Thailand Radio began to operate from Yunnan in southern China.

In addition, the CPT began to undertake a clandestine insurgency in rural Thailand. In 1960, it proclaimed that 'for Thailand there can never be any peaceful path, but only the way of armed struggle'. ${ }^{61}$ In 1962, CPT's 'Prediction for BE2505' was distributed in Thailand, calling for the establishment of a united front in order to oust the US and overthrow the Sarit military regime. ${ }^{62}$ For the Thai military, these changes precipitated an actual threat of communist insurgency in Thailand, which was supported and funded by foreign communists, especially the Chinese.

Fourth, Sarit pursued an American model of socio-economic 'development' in order to gain foreign investment and to fight communism. Sarit thus rescinded Phibun's economic nationalism and resuscitated liberalisation. Shortly after the coup, his government initiated Revolutionary Proclamation No. 11 as a plan to modernise the country, and Revolutionary Proclamation No. 33 to implement liberalism as economic policy. Sarit subsequently set up the National Economic Council in July 1959, and launched the first Six-Year National Economic Development Plan (1961-1966) in October 1960. He also cancelled import tax on all machinery for five years, which was enshrined in the Investment Promotion Act of 1962. In turn, the US increasingly provided Thailand with more economic aid. Most of it was used for military objectives,

60 Thak, Thailand.

61 Patrice de Beer, 'History and Policy of the Communist Party of Thailand', Journal of Contemporary Asia 8, no. 1 (1978): 164.

62 Surachart, United States Foreign Policy and Thailand Military Rule, 107. 
such as building the 450-mile Friendship Highway between Bangkok and Nong Khai near Laos. ${ }^{63}$ In other words, by adopting the concept of 'development' (karn pattana), Sarit promoted capitalism in Thailand.

Fifth, in the foreign policymaking process, Sarit monopolised power within the military group and thereby marginalised the roles of civilians - in particular, in the Ministry of Foreign Affairs (MFA). Although he appointed a civilian, Thanat Khoman, as foreign minister, Thanat's role was relatively marginal. ${ }^{64}$

In brief, the military regime of Sarit oversaw a major transformation in Thai politics and foreign affairs. His regime committed Thailand to an authoritarian road and a close alliance with the US. Most importantly, it established the discourse of anticommunism and, unlike his predecessors, linked the ideology inextricably with both Thai nationalism and royalism. By 1958, the Cold War discursive hegemony, including discourses of Americanism, anticommunism and antagonism with communist powers, was fully established and implemented in Thailand.

After Sarit's death in December 1963, his successor, Field Marshal Thanom Kittikachorn, continued the anticommunist discourse. By that time, Thailand perceived the communists, particularly the Chinese and North Vietnamese, as genuine 'threats' to national security. As Arne Kislenko put it:

[Thanom] was profoundly anticommunist, believing firmly that the threat [Beijing] and Hanoi posed to Thailand was real, immediate, and unyielding. Trying to accommodate communism was useless, and so too was a return to a more neutral foreign policy. ${ }^{65}$

While the nature of their relationship was unequal, Thailand and the US were increasingly dependent upon each other. Thanom saw the US as the guarantor of Thai security. The Tonkin Incident in 1964, which led to direct American involvement and escalation in the Vietnam War, made

63 Kullada Kesboonchoo Mead, 'A Revisionist History of Thai-US Relations', Asian Review 16 (2003): 59-60; Ukrist Pathmanand, 'Saharat America kap nayobai sethakit Thai' [The US and Thai Economic Policy] (MA thesis, Chulalongkorn University, 1983).

64 John Funston, 'The Role of the Ministry of Foreign Affairs in Thailand: Some Preliminary Observations', Contemporary Southeast Asia 9, no. 3 (December 1987): 236.

65 Arne Kislenko, 'Bamboo in the Wind: United States Foreign Policy and Thailand during the Kennedy and Johnson Administrations, 1961-1969' (PhD thesis, University of Toronto, 2000), 175. 
Thailand an invaluable anticommunist ally, or an 'unsinkable aircraft carrier. ${ }^{66}$ Benedict Anderson called this period the 'American Era' of Thai history. ${ }^{67}$

After stepping up the air war (in late 1964) and ground war (in July 1965) against Hanoi, the US Government under President Lyndon Johnson led the Thais to believe that the US would make a strong military commitment to protect Thai security and independence. Both countries concluded a secret military agreement, called the Contingency Plan of 1964. From then, the Thanom Government permitted the US to deploy its troops in the country, allowing for covert operations throughout Indochina to steadily expand, including the so-called 'secret war' in Laos. ${ }^{68}$ In order to support the bombing of North Vietnam, Thailand allowed the US access to strategic air bases across the country. American airplanes flew out of Thai bases, with 25,000 bombing flights in 1965, 79,000 in 1966, and 108,000 in 1967. Until 1967, the Thai Government publicly denied that the Americans bombed North Vietnam from Thai air bases. ${ }^{69}$ In 1967 , both governments signed the Joint Use and Air Defense Operations Agreement. In return, the US increased economic and military aid to the Thai military government. It provided the Thai Army with military hardware and advisors, while developing security programs, and launching counterinsurgency programs at the village level. Thailand also became an $\mathrm{R} \& \mathrm{R}$ (rest and recreation) centre for the US personnel in the region.

66 John LS Girling, Thailand: Society and Politics (Ithaca: Cornell University Press, 1981), 231.

67 Benedict Anderson, In the Mirror: Literature and Politics in Siam in the American Era (Bangkok: Duang Kamol, 1985).

68 In fact, there were actually more Thai 'boots on the ground' in the secret war in Laos than in Vietnam during the Vietnam War. See Sutayut, 'Thailand and the American Secret War'.

69 Randolph, The United States and Thailand, 76. During his visit to Washington DC in October 1965, Foreign Minister Thanat Khoman gave an interview to the Washington Post, acknowledging that US military involvement in Vietnam represented a strong commitment to the defence of Southeast Asia. He openly attacked those who advocated a policy of neutrality, suggesting that it was a concession to the communists. More interestingly, Thanat conceded that Thailand did not need 11,000-foot runways in the north-east for its own air force. He implicitly admitted Thai involvement with the American air war in Vietnam. As one summed up, 'It was a very Thai way of announcing Bangkok's commitment to Washington, and given the emphasis placed in plausible denial, it was clearly designed to elicit more support from the US'. Thanat Khoman, interview with Robert Eastabrook, The Washington Post, 11 October 1965, in Kislenko, 'Bamboo in the Wind', 216. 
Thailand's increasing involvement in Vietnam had some of the following characteristics. First, the Thai military firmly monopolised Thai foreign and security policymaking decisions. This marked the waning power of Foreign Minister Thanat and the MFA, which were almost entirely excluded from the country's foreign policy.

Second, with the exception of U-Tapao Air Base and Ramasun Radio Station, the stationing of US forces in Thailand was dealt with on an informal basis, with no written agreements. ${ }^{70}$ This was to avoid Congressional investigations for the US and difficult questions regarding sovereignty for the Thais.

Third, Thailand's close alignment with the US increased communist activities inside the country. In fact, the first official attack by the communist insurgents on Thai military forces in the rural areas only occurred in $1965 .{ }^{71}$ That is, anticommunist counterinsurgency programs began long before there was any serious communist threat in Thailand.

Fourth, Thailand's involvement with the Vietnam War weakened its foreign relations with the communist powers. In 1965, the Soviet Union denounced Thailand's pro-Americanism. When Soviet Premier Alexei Kosygin visited Hanoi in January 1965, he pledged to provide military aid and supplies to North Vietnam. Thai-Soviet relations further worsened and when the Association of Southeast Asian Nations (ASEAN) was established in August 1967, the Soviet Union complained about the anticommunist nature of the organisation. ${ }^{72}$

Also, since 1965, the PRC responded to the expanding influence of the US in the region, including Thailand, by providing direct support to the CPT and repeatedly attacking the Thai military government. It called on the CPT to step up its armed struggle to overthrow 'the reactionary Thanom government'. In 1965, Chinese Foreign Minister Marshal Chen Yi allegedly declared the 'hope to have a guerrilla war going in Thailand before the year is out'. ${ }^{73}$ Likewise, Liao Chengzhi, Chair of the Overseas Chinese Affairs Commission, announced that Beijing had 'unshirkable

70 Randolph, The United States and Thailand, 73.

71 Katherine A Bowie, Rituals of National Loyalty: An Anthropology of the State and the Village Scout Movement in Thailand (New York: Columbia University Press, 1997), 63.

72 Ganganath Jha, Foreign Policy of Thailand (New Delhi: Radiant Publishers, 1979), 75-77.

73 Quoted in John Wong, The Political Economy of China's Changing Relations with Southeast Asia (London: Macmillan Press, 1984), 164. 
obligations' to support 'the struggles of the people' of Thailand. ${ }^{74}$ The revival of communist insurgency, with Chinese sponsorship, alarmed the Thai military. In December 1965, the Thai Government, with American assistance, established the Communist Suppression Operations Command (CSOC) in order to oversee and coordinate anticommunist activities among different agencies. ${ }^{75}$

Fifth, Thailand at first provided military facilities for the US in the Vietnam War, then sent its own special forces to fight in Vietnam. This was in exchange for a huge amount of military assistance. The first unit deployed to Vietnam in the late 1960s was the Royal Thai Army Volunteer Force, or the so-called 'Black Panthers', consisting of 11,000 troops. ${ }^{76}$

Sixth, a vested interest in the US military presence grew among the higher echelons of the military elite, who became caught up in the intricate web of corruption. Their mutual demands and expectations also rose.

Lastly, as the Vietnam quagmire worsened and antiwar student protests and popular movements emerged across the world, including in Thailand, the promulgation of the February 1968 election and the return to a parliamentary system meant that Thai foreign and security policy was opened to more public scrutiny. ${ }^{77}$

Thus, by the 1960s, the discourse of anticommunism was arguably at its most deeply embedded in Thai politics and foreign affairs, inseparable from both pro-Americanism and antagonism with the communist powers.

However, the Tet Offensive, when South Vietnam was surprised by an attack by the North Vietnamese forces on the Vietnamese New Year in January 1968, led to new pressure in American politics. President Johnson declared he would not stand in the next election, and began to negotiate an end to the war. Subsequently, he halted the aerial bombings in Vietnam. Thailand had not been given any prior warning of this announcement, which infuriated many Thai leaders. Foreign Minister Thanat said that he did not fear 'the cessation of the bombing' itself, but 'the cessation of the hostilities'. For him, Thailand was

\footnotetext{
74 Quoted in Kislenko, 'Bamboo in the Wind', 219.

75 Saiyud Kerdphol, The Struggle for Thailand: Counter-insurgency, 1965-1985 (Bangkok: S. Research Center, 1986).

76 Randolph, The United States and Thailand, 79-80.

77 Kullada, 'The Cold War and Thai Democratization', 225.
} 
not opposed to the halting of the bombing of North Vietnam as such. But we would oppose the cessation of the bombing if it were to put the aggressive side in a position that will help them strike at us, at our soldiers, at our people, at the people in Vietnam, at the American and South Vietnamese soldiers who are fighting so bravely and also the Thai soldiers in South Vietnam. ${ }^{78}$

It was this shifting American policy that instigated discursive anxiety for the MFA, led by Thanat Khoman, which in turn started to conduct a more flexible diplomacy.

\subsection{Conclusion}

This chapter has traced a genealogy of the anticommunist discourse within the discursive context of Thai diplomacy. Although anticommunism was mentioned throughout diplomatic history, it became a hegemonic narrative only in the late 1950s. Thai governments under Sarit and Thanom, along with a military elite, became strongly attached to the anticommunist discourse and a pro-American stance during the Vietnam War. The identities of the military and conservatives were constructed as staunch anticommunists. The communists were discursively denounced and demonised as imminent 'threats' and Thailand's foreign relations with the USSR and the PRC became mutually antagonistic. In general, Thai diplomacy in the Cold War was neither flexible nor 'bending with the wind' at all. Rather, it was rigid and confrontational. This only began to change in the late 1960s as a consequence of an emergent discursive struggle. It was this struggle which will be explored through the rest of this book.

78 Thanat Khoman, 'View from Thailand', an ABC interview with Foreign Minister Thanat Khoman, 7 October 1967, in Collected Interviews of H.E. Dr. Thanat Khoman, Vol. 1: 1967, 100-101. 
This text is taken from A Genealogy of Bamboo Diplomacy: The Politics of Thai Détente with Russia and China, by Jittipat Poonkham, published 2022 by ANU Press, The Australian National University, Canberra, Australia.

doi.org/10.22459/GBD.2022.02 